\title{
Hydrological control of As concentrations in Bangladesh groundwater
}

\author{
M. Stute, ${ }^{1,2}$ Y. Zheng, ${ }^{2,3}$ P. Schlosser, ${ }^{2,4}$ A. Horneman, ${ }^{4}$ R. K. Dhar, ${ }^{3}$ S. Datta, ${ }^{2}$ \\ M. A. Hoque, ${ }^{5}$ A. A. Seddique, ${ }^{5}$ M. Shamsudduha, ${ }^{5}$ K. M. Ahmed, ${ }^{5}$ and A. van Geen ${ }^{2}$ \\ Received 11 August 2005; revised 17 January 2007; accepted 24 May 2007; published 26 September 2007. \\ [1] The elevated arsenic (As) content of groundwater from wells across Bangladesh and \\ several other South Asian countries is estimated to slowly poison at least 100 million \\ people. The heterogeneous distribution of dissolved arsenic in the subsurface complicates \\ understanding of its release from the sediment matrix into the groundwater, as well as the \\ design of mitigation strategies. Using the tritium-helium $\left({ }^{3} \mathrm{H} /{ }^{3} \mathrm{He}\right)$ groundwater dating \\ technique, we show that there is a linear correlation between groundwater age at depths \\ $<20 \mathrm{~m}$ and dissolved As concentration, with an average slope of $19 \mu \mathrm{g} \mathrm{L}^{-1} \mathrm{yr}^{-1}$ \\ (monitoring wells only). We propose that either the kinetics of As mobilization or the \\ removal of As by groundwater flushing is the mechanism underlying this relationship. In \\ either case, the spatial variability of As concentrations in the top $20 \mathrm{~m}$ of the shallow \\ aquifers can to a large extent be attributed to groundwater age controlled by the \\ hydrogeological heterogeneity in the local groundwater flow system.
}

Citation: Stute, M., et al. (2007), Hydrological control of As concentrations in Bangladesh groundwater, Water Resour. Res., 43, W09417, doi:10.1029/2005WR004499.

\section{Introduction}

[2] In many parts of the world, groundwater has proved to be a reliable source of drinking water that, unlike surface water, is typically not contaminated with human pathogens. In several South Asian countries, however, a massive switch of rural consumption to untreated groundwater supplied by millions of wells over the past few decades has turned into a disaster. In Bangladesh alone, an estimated 50 million people have been exposed to arsenic (As) levels in drinking water that exceed the World Health Organization (WHO) guideline of $10 \mu \mathrm{g} \mathrm{L}^{-1}$ for drinking water by up to 2 orders of magnitude [British Geological Survey and Department of Public Health Engineering (BGS and DPHE), 2001; Yu et al., 2003].

[3] Several large surveys show that elevated dissolved As concentrations are limited to the upper $100 \mathrm{~m}$ of the aquifers and that the As distribution is spatially very heterogeneous on scales of meters to kilometers [BGS and DPHE, 2001; van Geen et al., 2003b]. There are several fundamentally different hypotheses in the literature that attempt to explain the distribution of As in groundwaters in Bangladesh, and more than one may prove to be true in the end (see reviews

\footnotetext{
${ }^{1}$ Department of Environmental Science, Barnard College, New York, New York, USA.

${ }^{2}$ Lamont-Doherty Earth Observatory of Columbia University, Palisades, New York, USA.

${ }^{3}$ School of Earth and Environmental Science, Queens College, City University of New York, Flushing, New York, USA.

${ }^{4}$ Departments of Earth and Environmental Engineering and Earth and Environmental Sciences, Columbia University, New York, New York, USA.

${ }^{5}$ Department of Geology, University of Dhaka, Dhaka, Bangladesh.
}

Copyright 2007 by the American Geophysical Union.

0043-1397/07/2005WR004499 by, e.g., BGS and DPHE [2001], Harvey et al. [2006], McArthur et al. [2004], and Smedley and Kinniburgh [2002]). There is essentially universal agreement that the As is of natural origin, originally stemming from the source region of the sediments in the Himalayas $[B G S$ and DPHE, 2001; McArthur et al., 2004]. However, there is less agreement about the mineralogy of the dominant As source in the sediments [BGS and DPHE, 2001; Nickson et al., 1998, 2000], the biogeochemical processes that mobilize As [BGS and DPHE, 2001; Harvey et al., 2002; McArthur et al., 2004; Nickson et al., 1998; Polizzotto et al., 2006; Ravenscroft et al., 2001; Swartz et al., 2004; van Geen et $a l ., 2004]$, and the role of the groundwater flow regime in this process [Aggarwal et al., 2000; BGS and DPHE, 2001; Harvey et al., 2006; Klump et al., 2006; Polizzotto et al., 2006]. It is also not clear to what extent the distribution of dissolved As is controlled by the recent massive perturbations by irrigation pumping [Aggarwal et al., 2003; Harvey et al., 2002; Klump et al., 2006; McArthur et al., 2001; van Geen et al., 2003a]. A better understanding of all these processes is important for evaluating various groundwater management strategies in Bangladesh.

[4] The present study provides new evidence that hydrology is a major factor controlling the spatial distribution of As in aquifers $<20 \mathrm{~m}$ deep in the dissolved phase and possibly also the solid phase by documenting a systematic relationship between ${ }^{3} \mathrm{H} /{ }^{3} \mathrm{He}$ derived groundwater ages and dissolved As concentrations. It is important to increase our understanding of these shallow aquifers, many of which have As concentrations $<50 \mu \mathrm{g} \mathrm{L}^{-1}$ [BGS and DPHE, 2001; van Geen et al., 2003b], because they are likely to be the first to be affected by natural or anthropogenic changes in the hydrological cycle.

[5] The setting for our study is a $25 \mathrm{~km}^{2}$ area of Araihazar Upazila $\left(90^{\circ} 37^{\prime} \mathrm{E}, 23^{\circ} 47^{\prime} \mathrm{N}\right), 30 \mathrm{~km}$ east of 


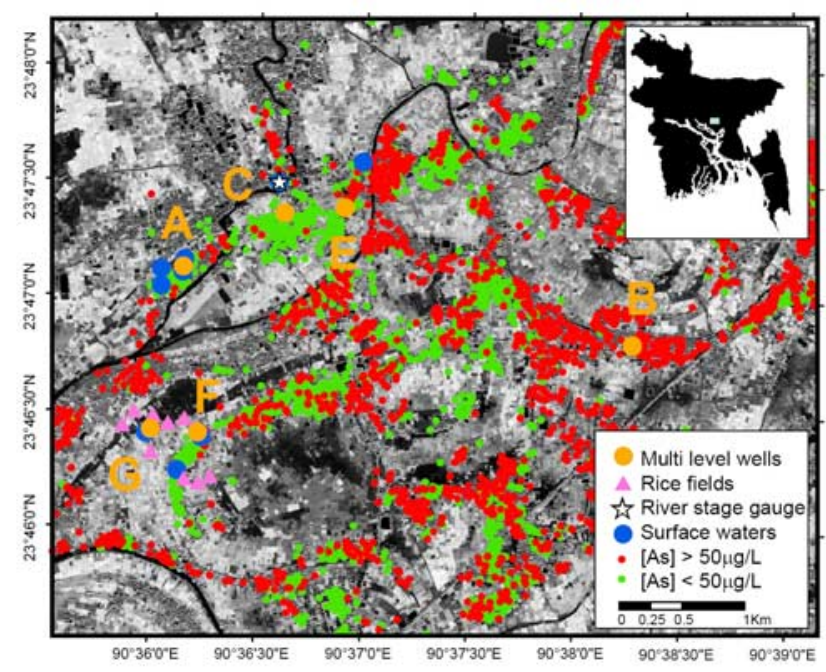

Figure 1. Study site in Araihazar Upazila, Bangladesh. The background is an IKONOS satellite image from November 2002 that was processed to emphasize the presence of water from the reflectance in the IR band (darker shades of gray). Green and red circles indicate locations and As concentrations of tube wells less than $20 \mathrm{~m}$ deep [van Geen et al., 2003b]. The insert shows the field area location on a map of Bangladesh. The locations of sampled private wells cover a larger area and are not shown. Pink triangles and blue circles mark the stable isotope collection sites of rice field and other surface water samples. The white star marks the location of the river stage gauge.

Dhaka, where for the past 6 years, Earth, health, and social scientists have engaged in an effort to understand the origins of elevated As in groundwater [van Geen et al., 2003b; Zheng et al., 2005], the health impacts of past exposure to As [Wasserman et al., 2004], and the mitigation option [van Geen et al., 2002].

\section{Methods}

[6] The vertical profiles of groundwater and sediment data presented in this study were obtained from six well nests located in a range of environments. The monitoring wells were installed within or on the outskirts of two villages with private wells $<20 \mathrm{~m}$ deep almost exclusively containing As concentrations $>50 \mu \mathrm{g} \mathrm{L}^{-1}$ (sites B and G), two villages with a mixed distribution of high- and low-As wells (sites A and E), and two villages where nearly all shallow wells have low As concentrations $\left(<50 \mu \mathrm{g} \mathrm{L}^{-1}\right.$, sites $\mathrm{C}$ and F) (Figure 1). The wells range from 5 to $90 \mathrm{~m}$ in depth and were installed in 2000-2001 using the local, reverse circulation, hand-percussion drilling technique [Ali, 2003; Horneman et al., 2004]. Their locations were chosen on the basis of an extensive survey of 6000 wells [van Geen et al., 2003b]. Each well nest consists of five to seven PVC pipes with $5 \mathrm{~cm}$ inner diameter and 0.9 or $1.5 \mathrm{~m}$ long slotted screens. The six sites labeled A, B, C, E, F, and G in Figure 1 were sampled in January 2003 for dissolved As, $\mathrm{Fe},{ }^{3} \mathrm{H}$, and dissolved noble gases, using a submersible Rediflo 2 (Grundfos) or a two-stage Geosquirt $12 \mathrm{~V}$ purger pump (Geotech). An additional set of 18 private tube wells covering a larger area, but located not more than $25 \mathrm{~km}$ away from the wells shown in Figure 1, were sampled in 1999, 2000, and 2001. These wells also cover a larger depth range $(9-40 \mathrm{~m})$. Samples were collected either by siphoning water with a tube out of the top of a hand pump or by using a submersible mechanically operated check valve pump (Waterra) after removal of the hand pump head. Sediment samples were collected at sites A and B with a split spoon sampler in January 2001 [Zheng et al., 2005] and in subsequent years using an evacuated needle sampler from sites E, F, and G [van Geen et al., 2004].

[7] Hydraulic heads and river stages were measured manually approximately every 2 weeks from February 2003 to February 2004, unless extensive flooding prevented visiting the monitoring sites (Figure 1). Relative hydraulic heads in multilevel wells were measured by inserting tubes into up to six wells and simultaneously lifting water levels to above ground by reducing the air pressure in the tubes with a hand pump [Pickens et al., 1978]. The average standard error of the relative head differences was $\pm 2 \mathrm{~mm}$.

[8] Hydraulic conductivities were determined by slug tests. Wells were pressurized with compressed $\mathrm{N}_{2}$, and the temporal response of the hydraulic head was measured using submersed pressure transducers with built-in data loggers (Leveloggers, Solinst). For each well, the experiment was repeated 6-12 times with two to four different pressures, and the hydraulic conductivity was determined by fitting the response curves [Butler and Garnett, 2000; Butler et al., 2003]. The standard error of the measurements was better than $5 \%$.

[9] Stable isotope $\left(\delta^{18} \mathrm{O}, \delta^{2} \mathrm{H}\right)$ samples were collected in $60 \mathrm{~mL}$ glass bottles with polyseal caps. Precipitation samples for stable isotope $\left(\delta^{18} \mathrm{O}, \delta^{2} \mathrm{H}\right)$ analysis were collected on the roof of Dhaka University as monthly composites in 2004. Surface water samples were collected from representative ponds and streams shown in Figure 1 from October 2003 to January 2005. Samples were collected from the multilevel wells in January 2003 and from irrigated rice fields $(n=10)$ on 21 March 2004 representing different degrees of evaporation (Figure 1). Measurements were performed at the Environmental Isotope Laboratory of the University of Waterloo with a precision of $0.1 \% 0\left(\delta^{18} \mathrm{O}\right)$ and $1 \%$ o $\left(\delta^{2} \mathrm{H}\right)$, respectively. Dissolved As and Fe concentrations were measured by high-resolution inductively coupled plasma-mass spectrometry (HR ICP-MS) [Horneman et al., 2004; Zheng et al., 2004, 2005], sediment $\mathrm{Fe}(\mathrm{II}) / \mathrm{Fe}$ ratios were measured by colorimetry on an $\mathrm{HCl}$ leach of the sediments [Horneman et al., 2004], and phosphate extractable As concentrations were measured by leaching bulk sediment using $\mathrm{Na}_{2} \mathrm{HPO}_{4}$ and subsequent HR ICP-MS analysis [Zheng et al., 2005].

[10] The ${ }^{3} \mathrm{H} /{ }^{3} \mathrm{He}$ dating technique can be applied to groundwater recharged after the onset of atmospheric testing of nuclear weapons that released radioactive ${ }^{3} \mathrm{H}$ which peaked in the early 1960s [Ekwurzel et al., 1994; Poreda et al., 1988; Schlosser et al., 1988, 1989; Solomon and Cook, 2000; Tolstikhin and Kamensky, 1969]. Analysis of ${ }^{3} \mathrm{H}$ in groundwater was performed using either $\sim 100 \mathrm{~cm}^{3}$ of water collected in glass bottles or with $\sim 16 \mathrm{~cm}^{3}$ of water collected in $\sim 1 \mathrm{~cm}$ outer diameter soft copper tubes using the ${ }^{3} \mathrm{He}$ ingrowth technique [Bayer et al., 1989; Clarke et al., 1976]. $\mathrm{He}$ and $\mathrm{Ne}$ isotope measurements were performed on 
Table 1. Chemical, Isotopic, and Hydraulic Data From the Multilevel Well Nests ${ }^{\mathrm{a}}$

\begin{tabular}{|c|c|c|c|c|c|c|c|c|c|c|c|c|c|}
\hline Well & $\begin{array}{l}\text { Depth, } \\
\text { m }\end{array}$ & $\begin{array}{l}{ }^{3} \mathrm{H}, \\
\mathrm{TU}\end{array}$ & $\pm 1 \sigma$ & $\begin{array}{l}{ }^{4} \mathrm{He}, \mathrm{cm}^{3} \\
\text { STP g }{ }^{-1}\end{array}$ & $\begin{array}{l}\mathrm{Ne}, \mathrm{cm}^{3} \\
\text { STP } \mathrm{g}^{-1}\end{array}$ & $\begin{array}{c}\delta^{3} \mathrm{He}, \\
\%\end{array}$ & $\begin{array}{c}{ }^{3} \mathrm{H}+{ }^{3} \mathrm{He} \\
\mathrm{TU}\end{array}$ & $\begin{array}{c}{ }^{3} \mathrm{H} /{ }^{3} \mathrm{He} \\
\text { Age, } \\
\text { years }\end{array}$ & $\begin{array}{c}\mathrm{Fe}, \\
\mathrm{mg} \mathrm{L}^{-1}\end{array}$ & $\begin{array}{c}\mathrm{As}, \\
\mu \mathrm{g} \mathrm{L}^{-1}\end{array}$ & $\begin{array}{c}\text { Recharge } \\
\text { Rate, } \\
\mathrm{m} \mathrm{yr}^{-1}\end{array}$ & $\begin{array}{c}\mathrm{K} \\
\mathrm{m} \mathrm{s}^{-1}\end{array}$ & $\begin{array}{c}\text { Relative } \\
\text { Hydraulic Head, } \\
\mathrm{cm}\end{array}$ \\
\hline A1 & 6.68 & 4.5 & 0.1 & $5.32 \mathrm{E}-08^{\mathrm{b}}$ & 2.07E-07 & 1.9 & 5.5 & 3.5 & 25.2 & 75.4 & 0.11 & $1.38 \mathrm{E}-04$ & 0.00 \\
\hline A2 & 9.78 & 4.2 & 0.1 & $5.29 \mathrm{E}-08$ & $2.17 \mathrm{E}-07$ & 10.3 & 7.7 & 10.8 & 10.5 & 133.8 & & $4.49 \mathrm{E}-04$ & -0.23 \\
\hline A3 & 12.68 & 5.4 & 1.0 & 4.14E-08 & $1.51 \mathrm{E}-07$ & 47.0 & 16.6 & 20.3 & 22.8 & 544.9 & & $4.65 \mathrm{E}-04$ & -0.54 \\
\hline A4 & 15.29 & 2.7 & 0.2 & $4.01 \mathrm{E}-08$ & $1.37 \mathrm{E}-07$ & 56.8 & 15.7 & 31.7 & 21.5 & 311.3 & & $1.07 \mathrm{E}-04$ & -0.53 \\
\hline B7 & 7.29 & 3.8 & 0.2 & $5.68 \mathrm{E}-08$ & $2.33 \mathrm{E}-07$ & -0.3 & 4.2 & 1.6 & 25.4 & 27 & 0.08 & 7.23E-05 & 0.00 \\
\hline B8 & 10.85 & 3.9 & 0.1 & $5.76 \mathrm{E}-08$ & $2.31 \mathrm{E}-07$ & 22.2 & 11.5 & 19.2 & 30.0 & 269 & & 4.14E-05 & 0.16 \\
\hline B3 & 14.34 & 3.4 & 0.3 & $5.57 \mathrm{E}-08$ & $2.18 \mathrm{E}-07$ & 20.0 & 10.1 & 19.3 & 21.2 & 530 & & $2.28 \mathrm{E}-04$ & -0.32 \\
\hline B9 & 19.39 & 1.7 & 0.1 & $5.76 \mathrm{E}-08$ & $2.20 \mathrm{E}-07$ & 12.6 & 6.1 & 23.3 & 27.5 & 377 & & $1.36 \mathrm{E}-04$ & -0.07 \\
\hline $\mathrm{C} 1$ & 4.66 & 3.6 & 0.2 & 7.29E-08 & $2.89 \mathrm{E}-07$ & -1.3 & 3.4 & 0.0 & 53.9 & 11.9 & 1.1 & $1.52 \mathrm{E}-04$ & 0.00 \\
\hline $\mathrm{C} 2$ & 8.26 & 4.0 & & $6.96 \mathrm{E}-08$ & $2.75 \mathrm{E}-07$ & -0.7 & 4.4 & 0.8 & 101.4 & 38.9 & & & -0.03 \\
\hline $\mathrm{C} 3$ & 11.28 & 3.8 & 0.2 & 7.33E-08 & $2.88 \mathrm{E}-07$ & 0.4 & 4.3 & 2.6 & 88.5 & 43.3 & & $2.36 \mathrm{E}-04$ & -0.17 \\
\hline $\mathrm{C} 4$ & 14.28 & 4.8 & 0.3 & $6.57 \mathrm{E}-08$ & $2.62 \mathrm{E}-07$ & 1.0 & 5.6 & 2.8 & 35.5 & 74.8 & & $1.92 \mathrm{E}-04$ & -0.31 \\
\hline E1 & 5.34 & 3.6 & 0.3 & $5.96 \mathrm{E}-08$ & 2.39E-07 & 6.4 & 6.1 & 9.6 & 2.7 & 42.4 & & $8.92 \mathrm{E}-05$ & 0.00 \\
\hline E2 & 8.31 & & & 7.01E-08 & $2.66 \mathrm{E}-07$ & 25.1 & & & 25.5 & 81.5 & & $1.74 \mathrm{E}-04$ & -0.04 \\
\hline E3 & 10.54 & 2.3 & 0.1 & 7.86E-08 & $2.93 \mathrm{E}-07$ & 6.8 & 5.7 & 18.1 & 26.0 & 173 & & $1.12 \mathrm{E}-04$ & -0.01 \\
\hline E4 & 13.68 & 3.9 & 0.3 & & & & & & 42.8 & 153 & & $5.63 \mathrm{E}-05$ & -0.16 \\
\hline F1 & 5.8 & 3.9 & 0.1 & 7.24E-08 & $2.84 \mathrm{E}-07$ & -0.6 & 4.0 & 0.8 & 0.1 & 0.4 & 0.5 & $1.94 \mathrm{E}-04$ & 0.00 \\
\hline $\mathrm{F} 2$ & 11.1 & & & 7.19E-08 & 2.79E-07 & -0.1 & & & 3.3 & 33.7 & & $3.45 \mathrm{E}-04$ & -0.22 \\
\hline $\mathrm{F} 3$ & 15.08 & 4.1 & 0.1 & $6.63 \mathrm{E}-08$ & $2.59 \mathrm{E}-07$ & 2.7 & 5.6 & 5.3 & 1.2 & 52.5 & & $3.35 \mathrm{E}-04$ & -0.40 \\
\hline F4 & 19.35 & 0.8 & 0.1 & $5.51 \mathrm{E}-08$ & $2.10 \mathrm{E}-07$ & 6.8 & 3.3 & 29.1 & 0.9 & 204.4 & & $2.31 \mathrm{E}-04$ & -0.61 \\
\hline G1 & 5.63 & 0.6 & 0.1 & $3.00 \mathrm{E}-08$ & $1.01 \mathrm{E}-07$ & 5.9 & 1.8 & 21.4 & 29.0 & 133 & & $1.26 \mathrm{E}-04$ & 0.00 \\
\hline G2 & 8.55 & 0.7 & 0.1 & $2.31 \mathrm{E}-08$ & & 2.7 & 1.3 & 13.1 & 26.5 & 161 & & 4.43E-05 & -0.02 \\
\hline G3 & 14.14 & 0.4 & 0.0 & $4.45 \mathrm{E}-08$ & $1.77 \mathrm{E}-07$ & 3.7 & 1.7 & 26.0 & 15.5 & 101 & & $4.12 \mathrm{E}-04$ & -0.16 \\
\hline
\end{tabular}

${ }^{\text {a }}$ The $\delta^{3} \mathrm{He}$ is the deviation in $\%$ of the measured ${ }^{3} \mathrm{He} /{ }^{4} \mathrm{He}$ ratio from that of atmospheric air. The ${ }^{3} \mathrm{H} /{ }^{3} \mathrm{He}$ age of one sample (C1) was negative but not statistically different from 0 and therefore was set to 0 .

${ }^{\mathrm{b}}$ Read 5.32E-08 as $5.32 \times 10^{-8}$.

$\sim 18 \mathrm{~cm}^{3}$ of water collected in copper tubes and measured by mass spectrometry [Ludin et al., 1997]. The precision and detection limit of the ${ }^{3} \mathrm{H}$ data were \pm 0.1 to $1.0 \mathrm{TU}$ and $0.05 \mathrm{TU}$, respectively (Tables 1 and 2) (1 TU is equivalent to $a{ }^{3} \mathrm{H} / \mathrm{H}$ ratio of $10^{-18}$ ). The analytical precisions of the $\mathrm{He}$ and $\mathrm{Ne}$ concentrations, as well as the He isotope ratios, were typically $< \pm 2 \%$ (standard error). However, occasionally, air inclusion into the sample containers during water collection, as well as gas fractionation caused by degassing, can lead to larger errors, mainly in the absolute concentrations of $\mathrm{He}$ and $\mathrm{Ne}$.

\section{Results}

[11] Our main focus in this section is on the monitoring wells because more high-quality data (e.g., sediment data at the same location, no degassing during sampling) are available for these compared to private tube wells equipped with hand pumps.

Table 2. The ${ }^{3} \mathrm{H} /{ }^{3} \mathrm{He}$ and As Data From Private Tube Wells in the Region ${ }^{\mathrm{a}}$

\begin{tabular}{|c|c|c|c|c|c|c|c|c|c|}
\hline Well & $\begin{array}{l}\text { Depth, } \\
\text { m }\end{array}$ & $\begin{array}{l}{ }^{3} \mathrm{H} \\
\mathrm{TU}\end{array}$ & $\begin{array}{l} \pm 1 \sigma, \\
\mathrm{TU}\end{array}$ & $\begin{array}{c}\mathrm{cm}^{3}{ }^{4} \mathrm{He}, \\
\mathrm{STP} \mathrm{g}^{-1}\end{array}$ & $\begin{array}{l}\mathrm{Ne} \\
\mathrm{cm}^{3} \mathrm{STP}^{-1}\end{array}$ & $\delta^{3} \mathrm{He}, \%$ & $\begin{array}{c}{ }^{3} \mathrm{H}+{ }^{3} \mathrm{He} \\
\mathrm{TU}\end{array}$ & $\begin{array}{l}{ }^{3} \mathrm{H} /{ }^{3} \mathrm{He} \\
\text { Age, yrs }\end{array}$ & $\begin{array}{c}\mathrm{As}, \\
\mu \mathrm{g} \mathrm{L}^{-}\end{array}$ \\
\hline 10 & 9 & 13.5 & 0.3 & $2.70 \mathrm{E}-08$ & $1.06 \mathrm{E}-07$ & 301.2 & 59.2 & 26.5 & 529.1 \\
\hline 20 & 23 & 5.4 & 0.1 & 4.47E-08 & $1.84 \mathrm{E}-07$ & 45.5 & 17.1 & 20.8 & 385.0 \\
\hline 26 & 24 & 6.2 & 0.4 & $6.10 \mathrm{E}-08$ & $2.44 \mathrm{E}-07$ & -0.9 & 6.3 & 0.3 & 33.0 \\
\hline 30 & 32 & 2.0 & 0.1 & $5.97 \mathrm{E}-08$ & $2.30 \mathrm{E}-07$ & 11.0 & 6.1 & 19.8 & 602.0 \\
\hline 52 & 9 & 3.9 & 0.2 & $5.52 \mathrm{E}-08$ & $2.22 \mathrm{E}-07$ & -3.4 & 3.9 & 0.0 & 14.0 \\
\hline 53 & 14 & 6.0 & 0.2 & $5.53 \mathrm{E}-08$ & $2.22 \mathrm{E}-07$ & 45.2 & 20.3 & 21.9 & 51.0 \\
\hline 54 & 13 & 5.4 & 0.3 & $4.97 \mathrm{E}-08$ & $2.00 \mathrm{E}-07$ & 6.4 & 7.6 & 6.1 & 305.0 \\
\hline 55 & 9 & 8.8 & 0.6 & $4.67 \mathrm{E}-08$ & $1.86 \mathrm{E}-07$ & 133.1 & 43.9 & 28.7 & 361.0 \\
\hline 102 & 11 & 4.0 & 0.6 & 4.92E-08 & $1.99 \mathrm{E}-07$ & 7.9 & 6.6 & 9.0 & 162.0 \\
\hline 125 & 23 & 18.0 & 0.7 & 5.63E- 08 & $2.22 \mathrm{E}-07$ & 322.4 & 121.3 & 33.9 & 893.0 \\
\hline 127 & 21 & 10.6 & 0.2 & 4.99E-08 & $1.97 \mathrm{E}-07$ & 203.6 & 67.4 & 34.3 & 1189.0 \\
\hline 133 & 18 & 5.9 & 0.7 & 4.47E-08 & $1.83 \mathrm{E}-07$ & 58.4 & 20.9 & 22.6 & 1371.0 \\
\hline 135 & 21 & 4.1 & 0.6 & $5.37 \mathrm{E}-08$ & $2.05 \mathrm{E}-07$ & 102.8 & 37.3 & 38.4 & 1020.0 \\
\hline 501 & 14 & 4.2 & 0.1 & $4.95 \mathrm{E}-08$ & $1.98 \mathrm{E}-07$ & 13.0 & 8.2 & 12.1 & 321.0 \\
\hline 502 & 14 & 5.1 & 0.1 & $4.31 \mathrm{E}-08$ & $1.66 \mathrm{E}-07$ & 49.5 & 17.4 & 21.9 & 646.7 \\
\hline 511 & 14 & 4.9 & 0.1 & $5.47 \mathrm{E}-08$ & $2.21 \mathrm{E}-07$ & 7.4 & 7.6 & 7.8 & 251.7 \\
\hline 513 & 9 & 4.7 & 0.1 & $4.68 \mathrm{E}-08$ & $1.89 \mathrm{E}-07$ & 7.0 & 7.0 & 6.9 & 280.1 \\
\hline 528 & & 4.5 & 0.1 & $4.52 \mathrm{E}-08$ & $1.85 \mathrm{E}-07$ & 1.8 & 5.4 & 3.2 & 36.2 \\
\hline
\end{tabular}

${ }^{a} \mathrm{The}{ }^{3} \mathrm{H} /{ }^{3} \mathrm{He}$ age of one sample (GB 52) was negative but not statistically different from 0 and was set to 0 . 

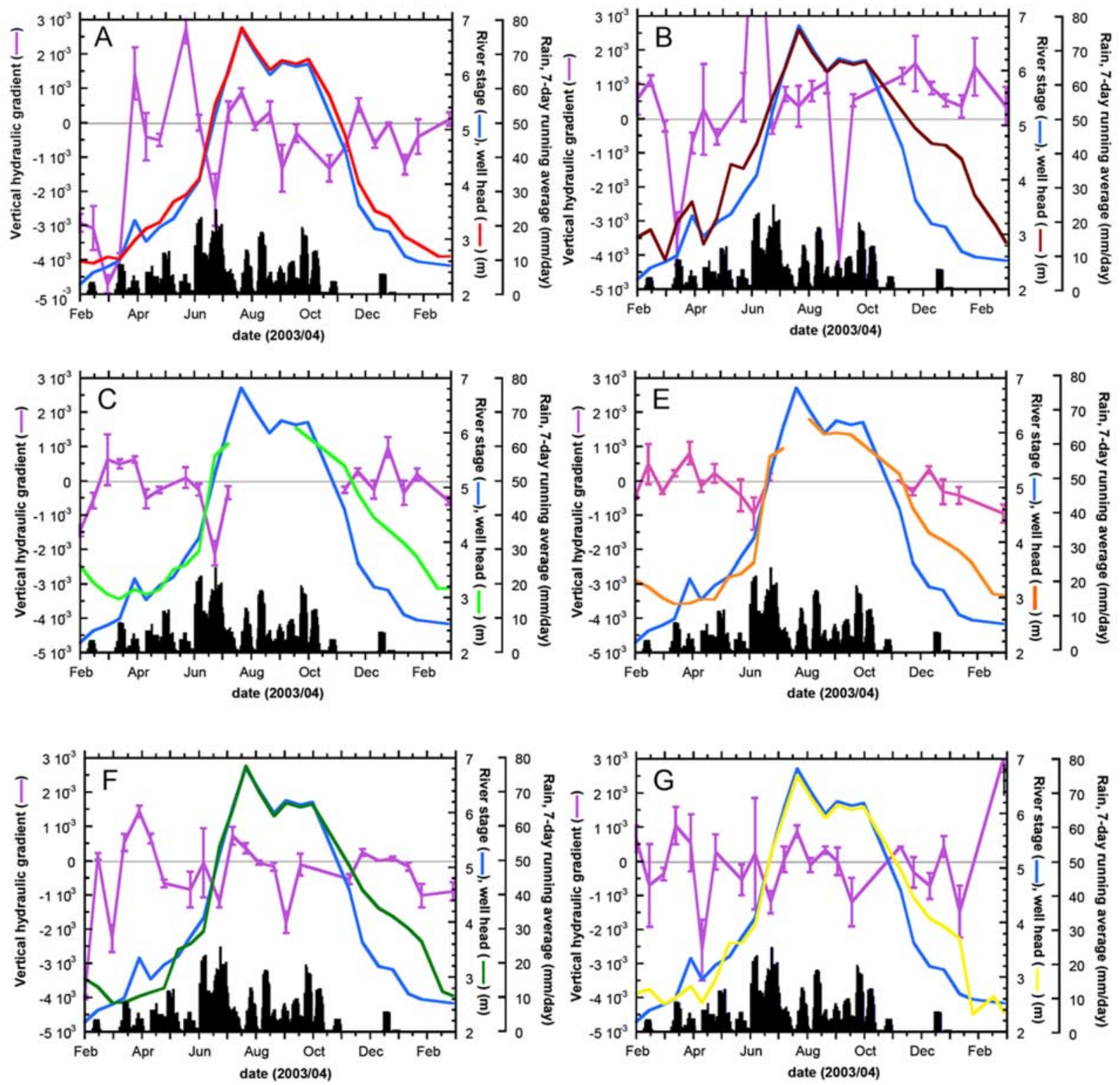

Figure 2. Hydraulic data for the six multilevel well sites (A, B, C, E, F, and G). The river stage (blue curve) was measured off a bridge upstream of site A (Figure 1). The purple curves indicate the vertical hydraulic gradient based on the shallowest two wells at the multi level well nests. Positive and negative values indicate upward and downward flow, respectively. Error bars are standard errors of means. Precipitation data (black histograms) are from Dhaka (station Dhaka-7) and are plotted as 7-day running means (Bangladesh Meteorological Department, Bangladesh Climate Data, 2006). The remaining curves show the hydraulic head of the shallowest wells at each of the multilevel sites.

[12] River stages and hydraulic heads measured at the six multilevel well sites cover a time period of 13 months (Figure 2). They show a seasonal pattern with the groundwater levels lagging behind the river stage slightly during the rising and considerably during the falling phase (Figure 2). Vertical gradients, determined by dividing the hydraulic head difference of the two shallowest wells at a site by the vertical distance of their screens, respond to abrupt changes in river stages and precipitation events as further discussed below.

[13] Stable isotope data of precipitation $(n=7)$ fall on the global meteoric waterline (GMWL, $\delta^{2} \mathrm{H}=8^{*} \delta^{18} \mathrm{O}+10 \%$ o [Craig, 1961]) with the average plotting close to the multiyear annual mean value for Bangkok, the closest, most representative station with a long-term record (see http:// isohis.iaea.org). Some groundwaters $(n=35)$ and most surface waters $(n=146)$ plot to the lower right of the curve indicating more or less evaporative enrichment (Figure 3). The highest degree of evaporation as measured by the deviation from the global meteoric waterline is shown by the irrigated rice fields $(n=10)$ and other surface waters collected during the dry season (November-March). Groundwater data mostly overlap with the GMWL and surface waters collected during the wet season and to a lesser extent with surface waters and rice field waters collected during the dry season. 


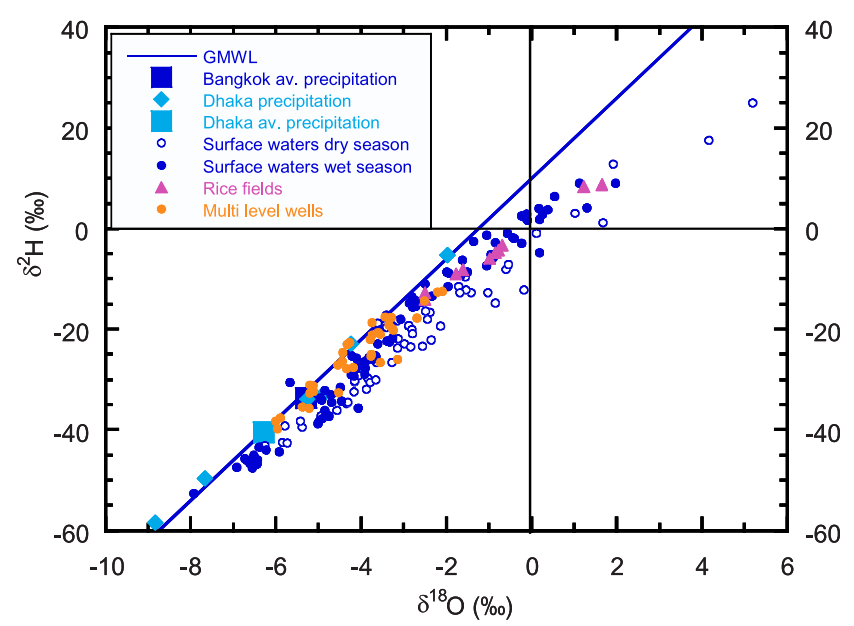

Figure 3. Stable isotope $\left(\delta^{18} \mathrm{O}, \delta^{2} \mathrm{H}\right)$ compositions of precipitation, groundwater, rice field irrigation water, and other surface waters collected from October 2003 to January 2005. The average annual isotopic composition of the Bangkok station of the IAEA/WMO network is also shown for reference (see http://isohis.iaea.org). Locations of sampling points are shown in Figure 1. One extremely depleted precipitation sample $\left(\delta^{18} \mathrm{O}=-11.1 \% ; \delta^{2} \mathrm{H}=\right.$ $-79.9 \%$ ) is omitted on the graph but is included in the calculation of the mean isotopic composition of precipitation. Surface water data were split into two groups, open blue circles reflect the dry season (November-February) and solid blue circles reflect the wet season (MarchOctober).

[14] Groundwater As concentrations range from $<1$ to $520 \mu \mathrm{g} \mathrm{L}^{-1}$ in the 23 monitoring wells installed in the depth range from 5 to $19 \mathrm{~m}$ (Table 1 and Figure 4a) and from 14 to $1371 \mu \mathrm{g} \mathrm{L}^{-1}$ in the private wells covering a depth range from 9 to $40 \mathrm{~m}$ (Table 2). At most monitoring well locations, dissolved As concentrations initially increase with depth and then reach a steady value or decrease to a somewhat lower concentration. The increase in As concentrations with depth is quite small at sites $\mathrm{C}$ and $\mathrm{F}$ where most private wells contain $<50 \mu \mathrm{g} \mathrm{L}^{-1}$ As. Although confined to a small area, this set of depth profiles obtained in Araihazar includes much of the range of dissolved As concentrations in shallow aquifers across Bangladesh [BGS and DPHE, 2001]. Dissolved Fe concentrations increase with depth for site $\mathrm{E}$, initially increase and then decrease at site $C$, and are fairly constant with depth for sites A, B, and F (Figure 4c). Dissolved As and Fe concentrations were also measured in monthly intervals from January to December of 2003 on samples from all monitoring wells by [Dhar, 2006]. Temporal variability during 2003 is small; all As and Fe depth trends shown in Figures $4 \mathrm{a}$ and $4 \mathrm{c}$ remain the same if the average annual concentrations are used instead of the result obtained in January 2003.

[15] Phosphate extractable As is fairly low and uniform at sites $\mathrm{F}$ and $\mathrm{C}$, higher and increasing with depth at site $\mathrm{A}$, and generally increasing but highly variable at site $\mathrm{B}$ (Figure 4d). The ratio of $\mathrm{Fe}(\mathrm{II})$ to total $\mathrm{Fe}$ measured on the sediments is fairly constant with depth at sites A, B, and $\mathrm{G}$, or increases slightly at sites F, C, and E (Figure 4e and Table 3). Annual averaged vertical hydraulic head gradients are small and downward for all sites, except for site B (Figure 4f). Hydraulic conductivity varies by 1 order of magnitude from $5 \times 10^{-5}$ to $5 \times 10^{-4} \mathrm{~m} \mathrm{~s}^{-1}$ (Figure $4 \mathrm{~g}$ ).

[16] An estimate of the time elapsed since recharge (apparent ${ }^{3} \mathrm{H} /{ }^{3} \mathrm{He}$ age) was obtained by measuring both ${ }^{3} \mathrm{H}$ and the concentrations of its stable daughter, the noble gas ${ }^{3} \mathrm{He}$. For most samples, concentrations of noble gases $\mathrm{He}$ and Ne slightly exceeded solubility equilibrium with the atmosphere due to excess air formation [Heaton and Vogel, 1981]. None of the samples contained significant amounts of radiogenic ${ }^{4} \mathrm{He}$. Six wells (two at site $\mathrm{A}$, one at site $\mathrm{G}$, and three private wells) showed significant losses of dissolved noble gases (up to $50 \%$ ). No bubbles were observed during sampling. Samples were collected in duplicate, and typically, their concentrations were reproducible within the uncertainty of the measurement. We therefore conclude that degassing for at least the monitoring wells did not take place during sampling but instead was due to in situ processes in the aquifer in agreement with findings by Klump et al. [2006]. Tritiogenic ${ }^{3} \mathrm{He}$, the sum of ${ }^{3} \mathrm{H}$ and tritiogenic ${ }^{3} \mathrm{He}$, and ${ }^{3} \mathrm{H} /{ }^{3} \mathrm{He}$ ages were calculated assuming that degassing took place during recharge, probably caused by gas stripping with $\mathrm{CH}_{4}$ or $\mathrm{CO}_{2}$ produced in organic-rich surface sediments [Mookherji et al., 2003]. Ne concentrations were used to separate tritiogenic ${ }^{3} \mathrm{He}$ from contributions from solubility equilibrium with the atmosphere and excess air [Schlosser et al., 1988]. Apparent ${ }^{3} \mathrm{H} /{ }^{3} \mathrm{He}$ ages measured on samples collected from the monitoring wells range from 0 to 32 years (Figure $4 \mathrm{~b}$ ). For all monitoring wells $<20 \mathrm{~m}$ deep where ${ }^{3} \mathrm{H} /{ }^{3} \mathrm{He}$ data were obtained, groundwater ages steadily increased with depth, except for site $\mathrm{G}$. The ${ }^{3} \mathrm{H} /{ }^{3} \mathrm{He}$ ages of the private tube wells range from 0 to 38 years and do not show a systematic trend with depth (Table 2). The ${ }^{3} \mathrm{H} /{ }^{3} \mathrm{He}$ ages of the sites with higher As concentrations (sites $\mathrm{A}$ and B; Figure 4b) are typically higher than at the sites with lower As concentrations (sites F and C).

[17] Groundwater dispersion or binary mixing between recently recharged groundwaters containing bomb-produced ${ }^{3} \mathrm{H}$ and older groundwater free of such inputs can be examined by adding the measured ${ }^{3} \mathrm{H}$ and tritiogenic ${ }^{3} \mathrm{He}$ content of a sample [Ekwurzel et al., 1994; Stute et al., 1997]. This combined measure of "stable ${ }^{3} \mathrm{H}$ " is a conservative tracer, the delivery of which was estimated for Bangladesh [Stute, 2001] and whose propagation in groundwaters can be predicted assuming typical rates of dispersion [Stute, 2001]. The stable ${ }^{3} \mathrm{H}$ content of the majority of groundwater samples is very close to the value predicted from such a simple model calculation (Figure 5). However, several data points, representing the deepest wells at sites $\mathrm{A}$, $\mathrm{B}, \mathrm{C}$, and $\mathrm{E}$, as well as all samples from site $\mathrm{G}$ and two private tube wells, fall significantly below the predicted tritium curve (Figure 5). The simplest explanation for these data points is dilution of groundwater of the corresponding ${ }^{3} \mathrm{H} /{ }^{3} \mathrm{He}$ age with up to $90 \%{ }^{3} \mathrm{H}$-free water recharged before the atmospheric nuclear weapons tests in the 1960s.

\section{Discussion}

\subsection{Recharge and Discharge}

[18] Our data support the general conceptual model of groundwater flow in Bangladesh [BGS and DPHE, 2001; Ravenscroft et al., 2005]: At the end of the dry season, river 

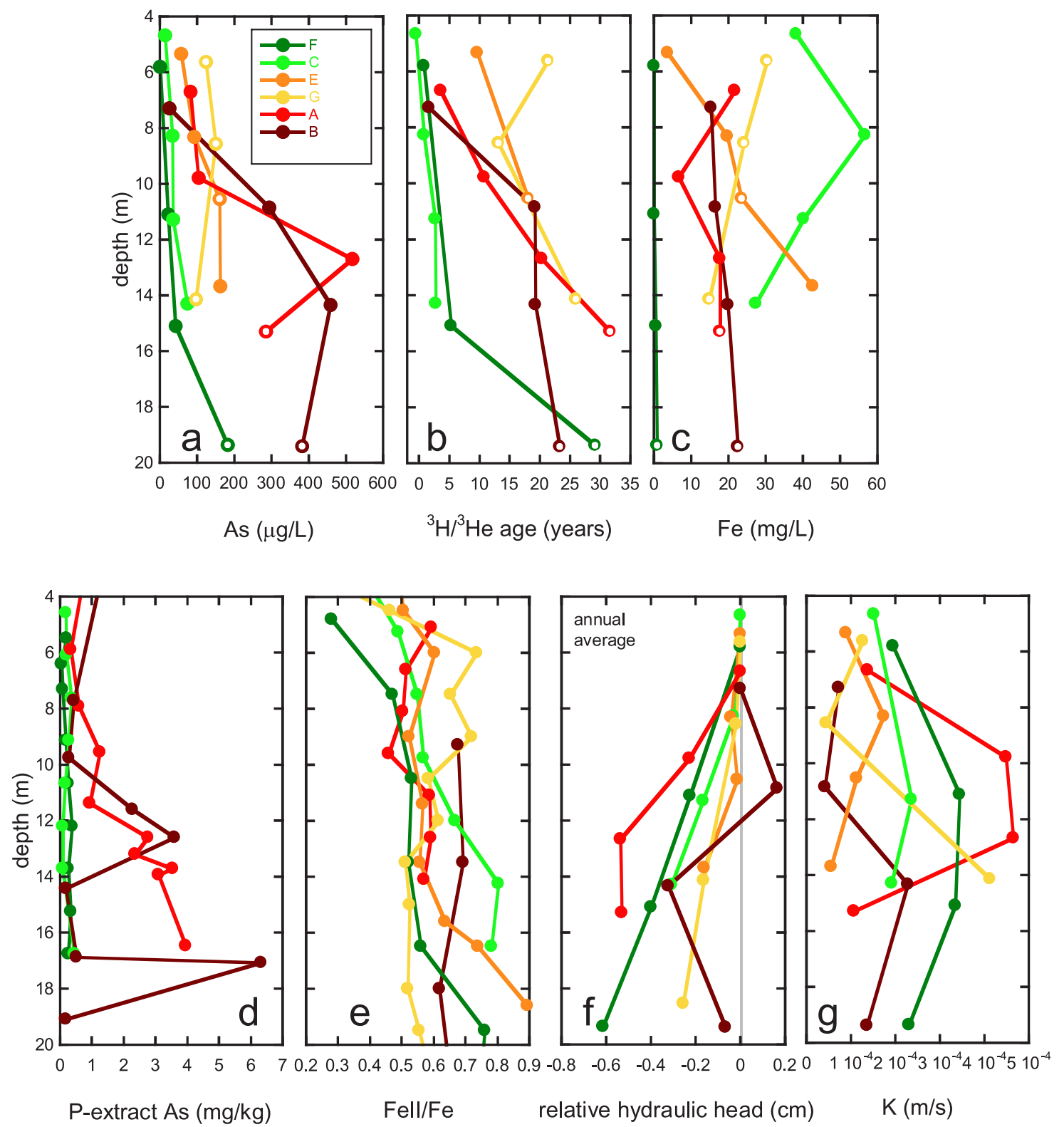

Figure 4. Profiles of groundwater (a) As concentrations, (b) ${ }^{3} \mathrm{H} /{ }^{3} \mathrm{He}$ ages, (c) dissolved $\mathrm{Fe}$ concentrations, (d) $\mathrm{PO}_{4}$-extractable As on the sediment phase, (e) leachable $\mathrm{Fe}(\mathrm{II}) / \mathrm{Fe}$ content of the sediment, (f) annual average relative hydraulic heads, and (g) hydraulic conductivity as a function of depth below surface for six well nests. The color scale from dark green to burgundy indicates increasing average dissolved As concentrations in this and other figures. Open symbols identify samples affected by mixing.

levels rise first and groundwater levels react for the most part with a slight delay (Figure 2). The sudden increase in river level at the end of March corresponds to an upward hydraulic head gradient in the shallowest two wells except for site $\mathrm{B}$, suggesting that river water enters the aquifer laterally. During the rising flank of the hydrograph, there are brief periods when groundwater leads the river and the shallow vertical hydraulic head points downward likely due to precipitation resulting in recharge. Lateral pressure pulses and vertical recharge can occur at the same time and cannot always be distinguished using vertical hydraulic gradients alone. During the main part of the wet season (JuneOctober), groundwater and river levels track each other closely with downward flow following major precipitation events. Finally, from October through the dry season, groundwater levels lag river levels considerably with continued downward flow until rivers begin to rise again at the beginning of the wet season. The different time lags between groundwater and river levels during the rising and falling flanks indicate that recharge occurs rapidly over a larger area through bank filtration, flooding, and infiltration of rainwater, while discharge occurs at fewer locations, likely into local surface water bodies or by localized evapotranspiration.

[19] Stable isotope data support the picture drawn on the basis of hydraulic data. Precipitation samples fall close to 
Table 3. Fe(II)/Fe Ratio Measured on Sediments in Araihazar

\begin{tabular}{|c|c|c|}
\hline Site & Depth, m & $\mathrm{Fe}(\mathrm{II}) / \mathrm{Fe}$ \\
\hline A & 5 & 0.59 \\
\hline A & 7 & 0.51 \\
\hline A & 8 & 0.50 \\
\hline A & 10 & 0.46 \\
\hline A & 11 & 0.59 \\
\hline A & 13 & 0.59 \\
\hline A & 14 & 0.57 \\
\hline B & 9 & 0.68 \\
\hline B & 14 & 0.69 \\
\hline B & 18 & 0.62 \\
\hline $\mathrm{C}$ & 3 & 0.37 \\
\hline C & 5 & 0.49 \\
\hline C & 8 & 0.55 \\
\hline C & 10 & 0.57 \\
\hline C & 12 & 0.67 \\
\hline $\mathrm{C}$ & 14 & 0.80 \\
\hline C & 17 & 0.78 \\
\hline E & 3 & 0.49 \\
\hline E & 5 & 0.50 \\
\hline E & 6 & 0.60 \\
\hline E & 9 & 0.52 \\
\hline E & 11 & 0.57 \\
\hline E & 14 & 0.56 \\
\hline E & 16 & 0.64 \\
\hline E & 17 & 0.74 \\
\hline E & 19 & 0.89 \\
\hline $\mathrm{F}$ & 5 & 0.28 \\
\hline $\mathrm{F}$ & 8 & 0.47 \\
\hline $\mathrm{F}$ & 11 & 0.53 \\
\hline $\mathrm{F}$ & 14 & 0.52 \\
\hline $\mathrm{F}$ & 17 & 0.56 \\
\hline F & 20 & 0.76 \\
\hline G & 3 & 0.19 \\
\hline $\mathrm{G}$ & 5 & 0.46 \\
\hline G & 6 & 0.74 \\
\hline $\mathrm{G}$ & 8 & 0.65 \\
\hline G & 9 & 0.72 \\
\hline $\mathrm{G}$ & 11 & 0.58 \\
\hline G & 12 & 0.61 \\
\hline $\mathrm{G}$ & 14 & 0.51 \\
\hline $\mathrm{G}$ & 15 & 0.53 \\
\hline $\mathrm{G}$ & 18 & 0.52 \\
\hline G & 20 & 0.55 \\
\hline
\end{tabular}

the global meteoric waterline, while surface waters show an evaporative signal, especially irrigated rice fields and other surface waters, both during the dry season (Figure 3). Stable isotope data of the groundwater samples fall on the meteoric water line or overlap with surface waters mostly during the wet season. The groundwater samples could also be mixtures of directly infiltrating rainwater, mildly evaporated surface waters, and smaller contributions of strongly evaporated surface waters including rice fields during the peak of the dry season.

[20] Recharge rates were estimated from the vertical ${ }^{3} \mathrm{H} /{ }^{3} \mathrm{He}$ age gradient for the shallowest two samples at each well nest not affected by mixing (Figure 4b) [Solomon et al., 1993]. The rates range from $\sim 0.11 \mathrm{~m} \mathrm{yr}^{-1}$ at site $\mathrm{A}$, over $0.52 \mathrm{~m} \mathrm{yr}^{-1}$ at site $\mathrm{F}$, to $1.1 \mathrm{~m} \mathrm{yr}^{-1}$ at site $\mathrm{C}$, assuming a typical porosity of 0.25 (Table 1 ). We cannot estimate a ${ }^{3} \mathrm{H} /{ }^{3} \mathrm{He}$-based recharge rate at sites $\mathrm{E}$ and $\mathrm{G}$ because samples are likely influenced by mixing. It is also problematic to calculate a local recharge rate for site $\mathrm{B}$ because the annual average vertical hydraulic gradient between the two shallowest wells is pointing upward (if we take the average gradient of the three shallowest wells at this site, the derived recharge rate is $0.08 \mathrm{~m} \mathrm{yr}^{-1}$, but it represents an average over a larger area if compared to the other sites). An independent estimate of the recharge rate can be derived from the hydraulic data. Our slug tests measure a radial hydraulic conductivity, which is likely very close to the horizontal hydraulic conductivity because of the anisotropy $\left(\mathrm{K}_{\mathrm{x}}(\mathrm{y}) / \mathrm{K}_{\mathrm{z}}\right)$ in fluvial sediments of at least a factor of 10 [Freeze and Cherry, 1979]. The average vertical conductivity was estimated for each site by dividing the average radial conductivity from the slug test measurements by 10 to account for anisotropy. Recharge rates determined from those conductivities and the average vertical hydraulic gradient using Darcy's law range from 0.05 to $0.6 \mathrm{~m} \mathrm{yr}^{-1}$. These estimates are uncertain because of the unknown anisotropy of the sediments but are nevertheless consistent with the ${ }^{3} \mathrm{H} /{ }^{3} \mathrm{He}$ derived values.

[21] Recharge rates reported by Dowling et al. [2003] on the basis of ${ }^{3} \mathrm{H} /{ }^{3} \mathrm{He}$ data for other areas in Bangladesh $(0.6 \pm$ $0.2 \mathrm{~m} \mathrm{yr}^{-1}$; uncertainty is one standard deviation of all estimates) are consistent with our observations, although their wells often had long screens and therefore many samples were affected by mixing with prebomb groundwater. In their heavily irrigated area $30 \mathrm{~km}$ south of Dhaka, Klump et al. [2006] report a ${ }^{3} \mathrm{H} /{ }^{3} \mathrm{He}$ age of 5 years at $9 \mathrm{~m}$ below ground, which would correspond to a similar re-

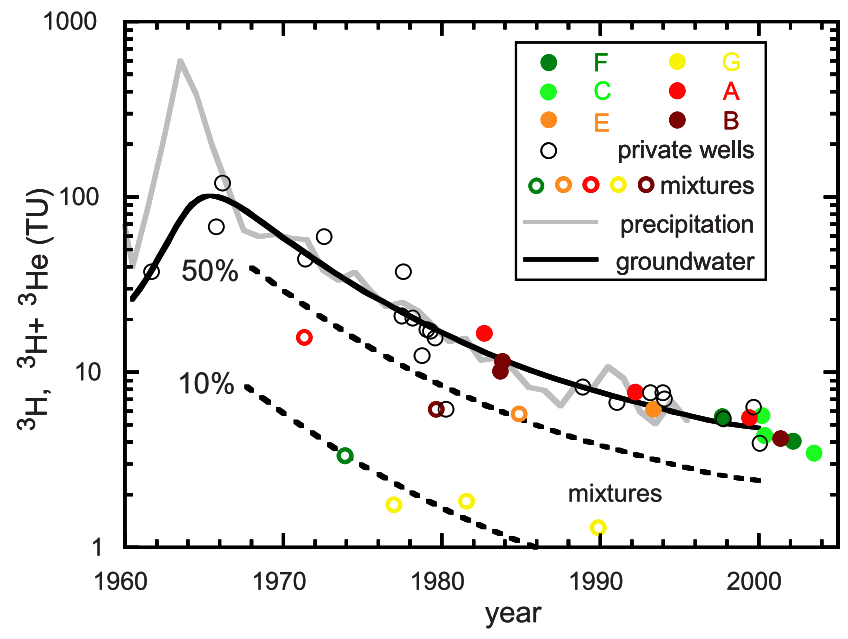

Figure 5. Predicted precipitation and measured groundwater ${ }^{3} \mathrm{H}$ and ${ }^{3} \mathrm{H}+{ }^{3} \mathrm{He}$ data collected from well nests (colored symbols) and private tube wells (open black symbols). Annual ${ }^{3} \mathrm{H}$ concentrations in Dhaka precipitation (gray curve) were reconstructed from neighboring monitoring stations and smoothed using a simple one-dimensional groundwater dispersion model (black curve) [Stute, 2001]. The groundwater samples were plotted as ${ }^{3} \mathrm{H}+{ }^{3} \mathrm{He}$ versus apparent recharge year determined by ${ }^{3} \mathrm{H} /{ }^{3} \mathrm{He}$ dating. Groundwater data points below the ${ }^{3} \mathrm{H}$ groundwater curve indicate mixing (open colored symbols). The dashed lines correspond to a simple two-component mixing model between a percentage of water with a recharge year given on the $x$ axis and prebomb groundwater. Open symbols identify samples that fall significantly below the input curves and are likely affected by mixing. 


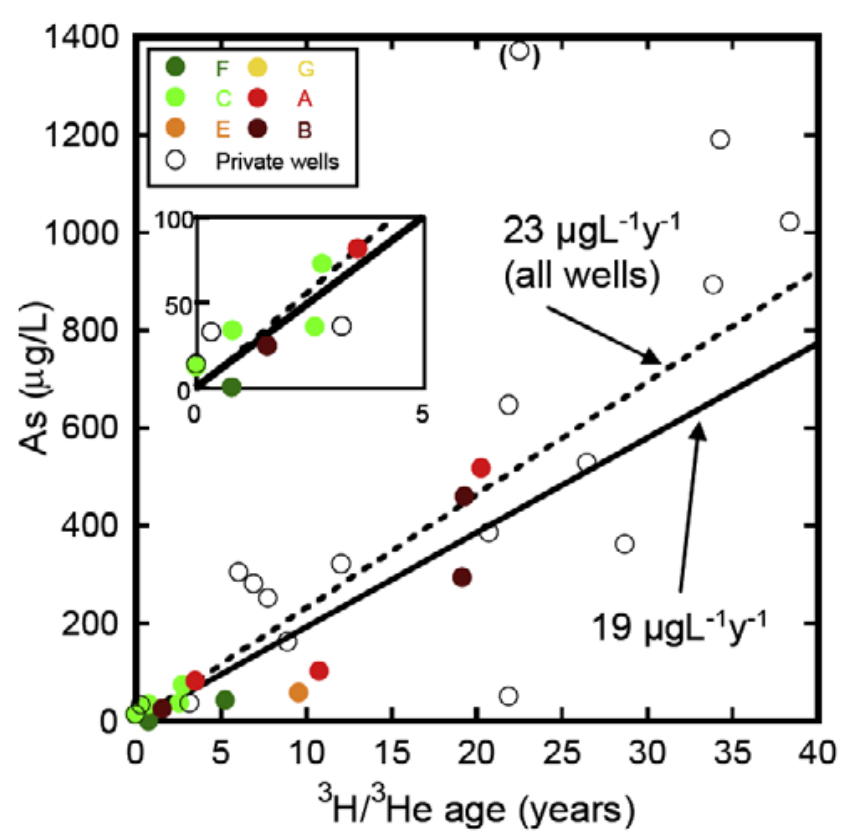

Figure 6. Dissolved total As concentrations as a function of ${ }^{3} \mathrm{H} /{ }^{3} \mathrm{He}$ age for samples not affected by mixing as defined in Figure 3. The insert highlights As concentrations for the young samples ranging from 0 to 5 years. The trend lines are forced through the origin. The solid black trend line fits the monitoring well nests only and has a slope of $19.4 \pm$ $1.9 \mu \mathrm{g} \mathrm{L}^{-1} \mathrm{yr}^{-1}\left(R^{2}=0.83, n=13\right.$, uncertainty is expressed as standard error). The dashed line fits the monitoring and private well data with a slope of $23.1 \pm 1.7 \mu \mathrm{g} \mathrm{L}^{-1} \mathrm{yr}^{-1}\left(R^{2}=\right.$ $0.77, n=29)$. The open circle highlighted in brackets is considered an outlier and is not included in the regression analysis.

charge rate of $\sim 0.5 \mathrm{~m} \mathrm{yr}^{-1}$, again assuming a porosity of 0.25 .

[22] Our tenfold range of recharge rates is likely related to topography (controlling location of recharge and discharge areas), climate and land use (influencing rates of evapotranspiration), the spatial distribution of groundwater pumping for irrigation purposes [Harvey et al., 2002], and the spatial variability of the hydraulic conductivity.

[23] Our study area is located between the floodplain of the present Meghna River to the east and the uplifted, older Madhupur terrace to the northwest [Goodbred et al., 2003]. The flat topography of the study area hides appreciable spatial variability in the grain size of subsurface deposits, typical of floodplain and deltaic environments where the streams conveying sediment to an area frequently change course [Coleman, 1969]. In some portions of the study area, quiescent conditions have resulted in the accumulation of layers of fine-grained clays or silts that overlie coarser sandy aquifers from which groundwater is drawn. In other areas, sandy deposits extend to the surface because strong river currents prevented accumulation of fine material (Z. Aziz et al., Impact of local recharge on arsenic concentrations in shallow aquifers inferred from the electromagnetic conductivity of soils in Araihazar, Bangladesh, submitted to Water Resources Research, 2007, hereinafter referred to as Aziz et al., submitted manuscript, 2007;
B. Weinman et al., Controls of floodplain stratigraphy and evolution on the distribution of shallow groundwater arsenic in Araihazar, Bangladesh, submitted to Geological Society of America Bulletin, 2007, hereinafter referred to as Weinman et al., submitted manuscript, 2007). Sediment cores collected with hand augers in areas surrounding the nests of monitoring wells (Aziz et al., submitted manuscript, 2007; Weinman et al., submitted manuscript, 2007) indicate that sandy material extends almost to the surface in areas where the recharge rate is higher, and groundwater therefore is younger (sites $\mathrm{C}$ and $\mathrm{F}$ ). In contrast, fine silts and clay layers were found to cap those aquifers where recharge is slower (sites A and B). Concentrations of As are generally lower at the sites with younger groundwater and higher at sites with older groundwater. These findings lead us to propose that local hydraulic conductivity of surface sediments plays an important role in controlling the rate of recharge of shallow aquifers in this region and, consequently, that local surface geology can be an important factor regulating concentrations of As in shallow groundwaters (Aziz et al., submitted manuscript, 2007; Weinman et al., submitted manuscript, 2007).

\subsection{Groundwater Age and Dissolved As}

[24] For monitoring well samples not affected by mixing with pre-1960 groundwater, the concentration of dissolved As increases approximately linearly with ${ }^{3} \mathrm{H} /{ }^{3} \mathrm{He}$ age (Figure 6). The slope of the regression line is $19.4 \pm 1.9 \mu \mathrm{g}$ $\mathrm{L}^{-1} \mathrm{yr}^{-1}\left(R^{2}=0.83, n=13\right.$; the uncertainty is expressed as standard error of the slope; solid black line in Figure 6). If samples are treated individually, the ratio of dissolved As and age ranges from 7 to $27 \mu \mathrm{g} \mathrm{L}^{-1} \mathrm{yr}^{-1}$ for the monitoring wells. All linear fits had intercepts not statistically different from 0 at the $95 \%$ confidence level and were forced through the origin. The slope is very similar for sites $\mathrm{C}$ and $\mathrm{F}$ in comparison to sites $\mathrm{A}$ and $\mathrm{B}$, although the recharge rates and As concentrations are very different (see insert in Figure 6). A linear fit of only the private tube wells (open black circles in Figure 6) yields a slope of $23.8 \pm 2.3 \mu \mathrm{g} \mathrm{L}^{-1} \mathrm{yr}^{-1}$ $\left(R^{2}=0.71, n=16\right.$, fit curve not shown). The difference between the two slopes is not statistically significant at the $95 \%$ confidence level. A fit of the combination of monitoring and private wells yields a slope of $23.1 \pm 1.7 \mu \mathrm{g} \mathrm{L}^{-1} \mathrm{yr}^{-1}$ ( $R^{2}=0.77, n=29$, broken line). The best estimate of the slope is likely that for the monitoring wells because the type of their construction and the aquifer they tap are more comparable and the sampling methods were more reliable. Also, three samples collected from private wells have apparent ages in the 35- to 40-year range, where the effects of dispersive mixing can considerably skew the relationship between apparent ${ }^{3} \mathrm{H} /{ }^{3} \mathrm{He}$ and actual groundwater age [Schlosser et al., 1989; Solomon et al., 1992]. Despite showing a larger scatter, the private wells follow the same trend as the monitoring wells.

[25] While a positive relationship between As and groundwater age has been noted before in a qualitative sense [Aggarwal et al., 2000; Klump et al., 2006], our study quantifies the correlation. In the following, we place the relationship between dissolved As and groundwater age in context of the main hypotheses concerning As mobilization that involve the role of the hydrology of the system. We do not discuss here in detail the geochemical process that actually mobilizes As other than to say that there are 
significant amounts (Figure 4d) of easily (phosphate) mobilizable As in the shallow aquifers in Araihazar, conditions are reducing (Figure 4e), and As can easily be dissolved when exposed to representative groundwater in the laboratory [van Geen et al., 2004; Zheng et al., 2004, 2005].

[26] A possible interpretation of the fairly uniform slope of the As/age relationship is that it reflects an accumulation rate along a flow path. However, previous experiments, conducted either in situ [Harvey et al., 2002] or in the laboratory using Bangladesh aquifer material [van Geen et al., 2004], yielded rates of As release from Bangladesh aquifer material that were up to 3 orders of magnitude higher because microbial activity was stimulated with the addition of reduced carbon. If our observation is interpreted as a measure of the rate of As release, we can estimate how much time is required before the mobilizable fraction of As contained in this shallow Bangladesh aquifer is exhausted. If we assume a constant As accumulation rate in groundwater, the rate at which As is released from the solid phase must be constant as well. Consequently, As is removed at a constant rate, independent of the residence time of the groundwater, at least for residence times less than 40 years. Groundwater cannot accumulate As indefinitely. Ultimately, the concentrations of As will reach a quasi-equilibrium value if allowed to age indefinitely, and removal rates will drop. Farther along the flow line, water might flow through sediments with changing biogeochemical conditions (perhaps less reducing, or lower-mobilizable As concentrations) that could either lower the water As concentrations or at least lower the rate of release. In our field area, As concentrations in the monitoring wells drop to lower values below $20 \mathrm{~m}$, but these samples do not contain ${ }^{3} \mathrm{H}$ and therefore do not allow us to extend the timescale of our study to groundwater below this depth.

[27] A simple calculation indicates that such a rate of As release can be sustained in the shallowest portion of the Holocene aquifer over much of its age. Phosphate and acid extractions applied to Holocene sediments associated with elevated As concentrations in groundwater yield an average value of $\sim 1.5 \mathrm{mg} \mathrm{kg}^{-1}$ for the concentration of mobilizable As and $\sim 3 \mathrm{mg} \mathrm{kg}^{-1}$ for bulk As [Zheng et al., 2005]. In a closed system the concentration of As in groundwater corresponding to a release of $1.5 \mathrm{mg} \mathrm{kg}^{-1}$ from the solid phase is equivalent to an As concentration of $11,250 \mu \mathrm{g} \mathrm{L}^{-1}$, assuming a porosity of 0.25 and a density of the solid phase of $2.5 \mathrm{~kg} \mathrm{~L}^{-1}$ [BGS and DPHE, 2001]. If the As mobilization rate of $\sim 20 \mu \mathrm{g} \mathrm{L}^{-1} \mathrm{yr}^{-1}$ were constant over centuries, the mobilizable pool of sedimentary As in the shallow aquifer near the recharge area would be removed in $\sim 600$ years. Looking back in time, assuming that the mobilization rate was constant over time and that initial bulk As concentrations were about $5 \mathrm{mg} \mathrm{kg}^{-1}$ [Chowdhury et al., 2003] to $10 \mathrm{mg} \mathrm{kg}^{-1}$, it would have taken as much as 750 to 1500 years for the As to reach today's level of $3 \mathrm{mg} \mathrm{kg}$, which is lower but of the same order of magnitude as the age of the shallowest $(<20 \mathrm{~m})$ Holocene sediments $(<6000$ years for depths less than $20 \mathrm{~m}$ [Goodbred et al., 2003], <4600 years for depths less than $29 \mathrm{~m}$ [Zheng et al., 2005]).

[28] Another possible explanation is based on the relationship between dissolved As concentrations and easily (phosphate) mobilizable sedimentary As concentrations
(Figures 4a and 4d). Assuming that the mobilization occurs fast relative to the groundwater residence time, lower dissolved As concentrations may be related to lower sedimentary As concentrations, which in turn are lower because at sites with lower residence times, more As has been lost by flushing into nearby streams over time. Gradual flushing of As out of an aquifer along various flow paths could also produce the observed broad relationship between As concentration and groundwater age.

[29] It has been hypothesized that dissolved organic matter drawn into aquifers by groundwater extraction during the past 2 decades might contribute to high As levels [Harvey et al., 2002]. This would seem to suggest that younger water would be associated with higher As levels, which is contrary to what was found here. We find that younger groundwater is lower in As and that site F, which is most affected by irrigation according to high-frequency hydraulic head measurements and irrigation well counts (not shown), has in fact the lowest average As concentration. Although the number of wells has increased exponentially in the area [van Geen et al., 2002], groundwater in the top $15 \mathrm{~m}$ at site $\mathrm{F}$ would have been recharged in the past 5 years, while considerable irrigation would have taken place in the area. The average age of the groundwater with the highest dissolved As levels at sites A and B is likely significant higher than the apparent ${ }^{3} \mathrm{H} /{ }^{3} \mathrm{He}$ age because of mixing (Figure 5). Even if taken at face value, however, groundwater of the deepest levels recharged not after 1972 (A) and 1980 (B) when irrigation was much less prevalent in the region [BGS and DPHE, 2001].

[30] Increased irrigation could, instead, decrease dissolved As concentrations due to export of dissolved As by enhanced flushing of the aquifer [McArthur et al., 2004] and perhaps by lowering dissolved As concentrations as consequence of a constant release rate but increased water flux due to irrigation. This notion is supported by the observation that As concentrations measured in irrigation wells are lower than in nearby monitoring wells [Harvey et al., 2003; Klump et al., 2006]. At least a simple scenario in which the vertical As profiles at sites F, C, A, B, and the private hand pumps are interpreted as mixing curves between old, highAs, and young, low-As, groundwater, is not consistent with the fact that the ${ }^{3} \mathrm{H} /{ }^{3} \mathrm{He}$ data for the most part plot so closely to the ${ }^{3} \mathrm{H}$ input curve (Figure 5).

[31] The analogy between the bell-shaped depth distribution of dissolved As in Bangladesh and that of the shape of contamination plumes at hazardous waste sites and the presence of high-As minerals near the water table [Breit et al., 2004] led to the idea that these minerals are the source and that the As is spread by advective and dispersive transport in the subsurface [Polizzotto et al., 2006, 2005]. However, under this scenario we would expect similar As concentrations for a wide range of ages or at least some very young groundwater samples with elevated As concentrations. We might even expect an inverse relationship between dissolved As and groundwater age due to increased dispersive mixing along flow lines. All these predictions are not consistent with our finding of an increase of As concentrations with groundwater age (Figure 6).

[32] Our main conclusion is that dissolved As concentrations are closely related to groundwater age on a timescale of $\sim 30$ years in our study area. Consequently, the 
groundwater flow regime controls much of the spatial variability of dissolved As concentrations in shallow aquifers in Araihazar. Although we are still uncertain about the underlying mechanism, the most likely scenarios are that As release kinetics control this relationship or that residence times control As removal in the aquifers. The other implication of our observations is that under either scenario, increased pumping would result in a reduction of dissolved As concentrations over time if increased irrigation does not affect the geochemistry of As mobilization. Only detailed studies of processes along flow paths in Bangladesh and elsewhere will ultimately resolve such questions.

[33] Acknowledgments. We thank four anonymous reviewers and H. J. Simpson, B. Mailloux, B. Weinman, and S. Goodbred for their comments on the manuscript. Funding for this study was provided by the U.S. NIEHS/Superfund Basic Research Program P42ES10349. This is LDEO contribution 7005 .

\section{References}

Aggarwal, P. K., A. R. Basu, and R. J. Poreda (2000), Isotope hydrology of groundwater in Bangladesh: Implications for characterisation and mitigation of arsenic in groundwater, TC Project BGD/8/016, Int. At. Energy Agency, Vienna.

Aggarwal, P. K., A. R. Basu, and K. M. Kulkarni (2003), Comment on "Arsenic mobility and groundwater extraction in Bangladesh" (I), Science, 300, 584B-U581.

Ali, M. (2003), Review of drilling and tubewell technology for groundwater irrigation, in Groundwater Resources and Development in Bangladesh: Background to the Arsenic Crisis, Agricultural Potential, and the Environment, edited by A. A. Rahman and P. Ravenscroft, pp. 197-219, Univ. Press Ltd., Dhaka.

Bayer, R., P. Schlosser, G. Boenisch, H. Rupp, F. Zaucker, and G. Zimmek (1989), Performance and blank components of a mass spectrometric system for routine measurement of helium isotopes and tritium by the ${ }^{3}$ He ingrowth method, Sitzungsber. 5, pp. 241-279, Heidelberger Akad. der Wiss., Math.-Nat. Klasse, Jahrgang, Heidelberg, Germany.

British Geological Survey and Department of Public Health Engineering (BGS and DPHE) (2001), Arsenic Contamination of Groundwater in Bangladesh, Keyworth, U. K.

Breit, G., A. L. Foster, R. B. Perkins, J. C. Yount, T. King, and A. H. Welch (2004), As-rich ferric oxyhydroxide enrichments in the shallow subsurface of Bangladesh, in Water-Rock Interactions, edited by R. B. Wanty and I. Seal, pp. 1457-1461, Taylor and Francis, London.

Butler, J. J., and E. J. Garnett (2000), Simple procedures for analysis of slug tests in formations of high hydraulic conductivity using spreadsheet and scientific graphics software, Rep. OFR 2000-40, Kans. Geol. Surv., Lawrence.

Butler, J. J., E. J. Garnett, and J. M. Healey (2003), Analysis of slug tests in formations of high hydraulic conductivity, Ground Water, 41, 620-630.

Chowdhury, M. A. I., M. F. Ahmed, and A. Ali (2003), Influence of upstream sediment on arsenic contamination of groundwater in Bangladesh, paper presented at Fate of Arsenic in the Environment, Bangladesh Univ. of Eng. and Technol. and United Nations Univ., Dhaka, Bangladesh.

Clarke, W. B., W. J. Jenkins, and Z. Top (1976), Determination of tritium by mass-spectrometric measurement of He-3, Int. J. Appl. Radiat. Isot., $27,515-522$.

Coleman, J. M. (1969), Brahmaputra River-Channel processes and sedimentation, Sediment. Geol., 3, 129-239.

Craig, H. (1961), Isotopic variations in meteoric waters, Science, 133, $1702-1703$.

Dhar, R. K. (2006), Arsenic and groundwater properties of Araihazar, Bangladesh, PhD. dissertation, City Univ. of New York, New York.

Dowling, C. B., et al. (2003), The groundwater geochemistry of the Bengal Basin: Weathering, chemsorption, and trace metal flux to the oceans, Geochim. Cosmochim. Acta, 67, 2117-2136.

Ekwurzel, B., P. Schlosser, W. M. Smethie, L. N. Plummer, E. Busenberg, R. L. Michel, R. Weppernig, and M. Stute (1994), Dating of shallow groundwater: Comparison of the transient tracers ${ }^{3} \mathrm{H} /{ }^{3} \mathrm{He}$, chlorofluorocarbons, and ${ }^{85} \mathrm{Kr}$, Water Resour. Res., 30, $1693-1708$.

Freeze, R. A., and J. A. Cherry (1979), Groundwater, vol. xvi, 604 pp., Prentice-Hall, Englewood Cliffs, N. J.
Goodbred, S. L., S. A. Kuehl, M. S. Steckler, and M. H. Sarker (2003), Controls on facies distribution and stratigraphic preservation in the Ganges-Brahmaputra delta sequence, Sediment. Geol., 155, 301-316.

Harvey, C. F., et al. (2002), Arsenic mobility and groundwater extraction in Bangladesh, Science, 298, 1602-1606.

Harvey, C. F., et al. (2003), Reply to comment on "Arsenic mobility and groundwater extraction in Bangladesh," Science, 300, 584.

Harvey, C. F., et al. (2006), Groundwater dynamics and arsenic contamination in Bangladesh, Chem. Geol., 228, 112-136.

Heaton, T. H. E., and J. C. Vogel (1981), Excess air in groundwater, J. Hydrol., 50, 201-216.

Horneman, A., et al. (2004), Decoupling of As and Fe release to Bangladesh groundwater under reducing conditions. part 1: Evidence from sediment profiles, Geochim. Cosmochim. Acta, 68, 3459-3473.

Klump, S., R. Kipfer, O. A. Cirpka, C. F. Harvey, M. S. Brennwald, K. N. Ashfaque, A. B. M. Badruzzaman, S. J. Hug, and D. M. Imboden (2006), Groundwater dynamics and arsenic mobilization in Bangladesh assessed using noble gases and tritium, Environ. Sci. Technol., 40, 243-250.

Ludin, A., R. Weppernig, G. Boenisch, and P. Schlosser (1997), Mass spectrometric measurement of helium isotopes and tritium, internal report, Lamont-Doherty Earth Obs., Palisades, N. Y.

McArthur, J. M., P. Ravenscroft, S. Safiulla, and M. F. Thirlwall (2001), Arsenic in groundwater: Testing pollution mechanisms for sedimentary aquifers in Bangladesh, Water Resour. Res., 37, 109-117.

McArthur, J. M., et al. (2004), Natural organic matter in sedimentary basins and its relation to arsenic in anoxic ground water: The example of West Bengal and its worldwide implications, Appl. Geochem., 19, 1255-1293.

Mookherji, S., G. W. McCarty, and J. T. Angier (2003), Dissolved gas analysis for assessing the fate of nitrate in wetlands, J. Am. Water Resour. Assoc., 39, 381-387.

Nickson, R., J. McArthur, W. Burgess, K. M. Ahmed, P. Ravenscroft, and M. Rahman (1998), Arsenic poisoning of Bangladesh groundwater, Nature, 395, 338.

Nickson, R. T., J. M. McArthur, P. Ravenscroft, W. G. Burgess, and K. M. Ahmed (2000), Mechanism of arsenic release to groundwater, Bangladesh and West Bengal, Appl. Geochem., 15, 403-413.

Pickens, J. F., J. A. Cherry, G. E. Grisak, W. F. Merritt, and B. A. Risto (1978), Multilevel device for groundwater sampling and piezometric monitoring, Ground Water, 16, 322-327.

Polizzotto, M. L., C. F. Harvey, S. R. Sutton, and S. Fendorf (2005), Processes conducive to the release and transport of arsenic into aquifers of Bangladesh, Proc. Natl. Acad. Sci. U. S. A., 102, 18,819-18,823.

Polizzotto, M. L., C. F. Harvey, G. C. Li, B. Badruzzman, A. Ali, M. Newville, S. Sutton, and S. Fendorf (2006), Solid-phases and desorption processes of arsenic within Bangladesh sediments, Chem. Geol., 228, $97-111$.

Poreda, R. J., T. E. Cerling, and D. K. Salomon (1988), Tritium and helium isotopes as hydrologic tracers in a shallow unconfined aquifer, J. Hydrol., 103, 1-9.

Ravenscroft, P., J. M. McArthur, and B. A. Hoque (2001), Geochemical and paleohydrological controls on pollution of groundwater by arsenic, in Arsenic Exposure and Health Effects, edited by W. R. Chapppell et al., pp. 53-77, Elsevier, New York.

Ravenscroft, P., W. G. Burgess, K. M. Ahmed, M. Burren, and J. Perrin (2005), Arsenic in groundwater of the Bengal Basin, Bangladesh: Distribution, field relations, and hydrogeological setting, Hydrogeol. J., 13, $727-751$.

Schlosser, P., M. Stute, H. Dorr, C. Sonntag, and K. O. Munnich (1988), Tritium ${ }^{3} \mathrm{He}$ dating of shallow groundwater, Earth Planet. Sci. Lett., 89, $353-362$.

Schlosser, P., M. Stute, C. Sonntag, and K. O. Munnich (1989), Tritiogenic ${ }^{3} \mathrm{He}$ in shallow groundwater, Earth Planet. Sci. Lett., 94, 245-256.

Smedley, P. L., and D. G. Kinniburgh (2002), A review of the source, behaviour and distribution of arsenic in natural waters, Appl. Geochem., $17,517-568$.

Solomon, D. K., and P. G. Cook (2000), ${ }^{3} \mathrm{H}$ and ${ }^{3} \mathrm{He}$, in Environmental Tracers in Subsurface Hydrology, edited by P. G. Cook and A. L. Herczeg, pp. 397-424, Springer, New York.

Solomon, D. K., R. J. Poreda, S. L. Schiff, and J. A. Cherry (1992), Tritium and $\mathrm{He}-3$ as groundwater age tracers in the Borden aquifer, Water Resour. Res., 28, 741-755.

Solomon, D. K., S. L. Schiff, R. J. Poreda, and W. B. Clarke (1993), A validation of the ${ }^{3} \mathrm{H} /{ }^{3} \mathrm{He}$ method for determining groundwater recharge, Water Resour. Res., 29, 2951-2962.

Stute, M. (2001), ${ }^{3} \mathrm{H}$ in precipitation in Bangladesh, in Groundwater Arsenic Contamination in the Bengal Delta Plain of Bangladesh Pro- 
ceedings of the KTH-Dhaka University Seminar, edited by G. Jacks et al., KTH Spec. Publ. TRITA-AMI Rep. 3084, pp. 109-117, Univ. of Dhaka, Dhaka, Bangladesh.

Stute, M., J. Deak, K. Revesz, J. K. Bohlke, E. Deseo, R. Weppernig, and P. Schlosser (1997), Tritium $/{ }^{\beta} \mathrm{He}$ dating of river infiltration: An example from the Danube in the Szigetkoz area, Hungary, Ground Water, 35, 905-911.

Swartz, C. H., N. K. Blute, B. Badruzzman, A. Ali, D. Brabander, J. Jay, J. Besancon, S. Islam, H. F. Hemond, and C. F. Harvey (2004), Mobility of arsenic in a Bangladesh aquifer: Inferences from geochemical profiles, leaching data, and mineralogical characterization, Geochim. Cosmochim. Acta, 68, 4539-4557.

Tolstikhin, I. N., and I. L. Kamensky (1969), Determination of groundwater ages by the $\mathrm{T}^{3} \mathrm{He}$ method, Geochem. Int., 6, 810-811.

van Geen, A., et al. (2002), Promotion of well-switching to mitigate the current arsenic crisis in Bangladesh, Bull. W. H. O., 80, 732-737.

van Geen, A., Y. Zheng, M. Stute, and K. M. Ahmed (2003a), Comment on "Arsenic mobility and groundwater extraction in Bangladesh" (II), Science, 300, 584C.

van Geen, A., et al. (2003b), Spatial variability of arsenic in 6000 tube wells in a $25 \mathrm{~km}^{2}$ area of Bangladesh, Water Resour. Res., 39(5), 1140, doi:10.1029/2002WR001617.

van Geen, A., J. Rose, S. Thoral, J. M. Garnier, Y. Zheng, and J. Y. Bottero (2004), Decoupling of As and Fe release to Bangladesh groundwater under reducing conditions. part II: Evidence from sediment incubations, Geochim. Cosmochim. Acta, 68, 3475-3486.
Wasserman, G. A., et al. (2004), Water arsenic exposure and children's intellectual function in Araihazar, Bangladesh, Environ. Health Perspect., $112,1329-1333$.

Yu, W. H., C. M. Harvey, and C. F. Harvey (2003), Arsenic in groundwater in Bangladesh: A geostatistical and epidemiological framework for evaluating health effects and potential remedies, Water Resour. Res., 39(6), 1146, doi:10.1029/2002WR001327.

Zheng, Y., M. Stute, A. van Geen, I. Gavrieli, R. Dhar, H. J. Simpson, P. Schlosser, and K. M. Ahmed (2004), Redox control of arsenic mobilization in Bangladesh groundwater, Appl. Geochem., 19, 201-214.

Zheng, Y., et al. (2005), Geochemical and hydrogeological contrasts between shallow and deeper aquifers in two villages of Araihazar, Bangladesh: Implications for deeper aquifers as drinking water sources, Geochim. Cosmochim. Acta, 69, 5203-5218.

K. M. Ahmed, M. A. Hoque, A. A. Seddique, and M. Shamsudduha, Department of Geology, Curzon Hall Campus, University of Dhaka, Dhaka 1000, Bangladesh.

S. Datta, P. Schlosser, M. Stute, and A. van Geen, Lamont-Doherty Earth Observatory of Columbia University, 61 Route 9W, Palisades, NY 10964, USA. (martins@ldeo.columbia.edu)

R. K. Dhar and Y. Zheng, School of Earth and Environmental Science, Queens College, City University of New York, 42-12 50th Avenue, Flushing, NY 11377, USA.

A. Horneman, Departments of Earth and Environmental Engineering and Earth and Environmental Sciences, Columbia University, Mail Code 5505, 557 Schermerhorn Extension, New York, NY 10027, USA. 